Mateusz Mirys

\title{
Świat opuszczony przez Boga w serialu The Wire
}

"Jesteśmy w Baltimore, tu bogowie cię nie ocalą" - autorem tego zdania jest Ervin Burrell, jeden z drugoplanowych bohaterów serialu The Wire. Piastuje on wysokie stanowisko w serialowym departamencie policji w Baltimore i jest typowym biurokratą oraz oportunistą. Przywołane słowa padają podczas składania przez jednego z oficerów (majora Colvina) raportu dotyczącego skali wykroczeń. Major zostaje przez Burrella („w prostych, żołnierskich słowach”) „pouczony”, że jeśli liczba wykroczeń w statystyce nie spadnie, pożegna się on ze stanowiskiem (sezon trzeci, odcinek „Dead Soldiers”, 26:11). Fabularna wymowa sceny jest w serialu jasna: Colvin ma zwyczajnie zmanipulować (poprzez odpowiednie zabiegi operacyjne) statystykę. Natomiast do jakich „bogów” odnosi się Burrell? Mówiąc: „Jesteśmy w Baltimore - tu bogowie cię nie ocalą" daje do zrozumienia Colvinowi, że jest on skazany w osiągnięciu „odpowiednich” wyników na samego siebie. W kontekście moich poniższych rozważań wydaje się jednak, że przez „bogów” nie ma on na myśli „szczęścia”, „losu” czy innej, nadnaturalnej siły. Burrellowi chodzi tu raczej o instytucje, które The Wire stara się obrazować, w tym reprezentowane przez siebie władze departamentu policji. Colvin, przeprowadzający prywatny eksperyment społeczny z depenalizacją posiadania i używania narkotyków, który powoduje znaczną poprawę bezpieczeństwa na ulicach Baltimore, nie może liczyć na swoich zwierzchników. Poddani presji polityków i mediów, tkwią w przeróżnych koteryjnych układach i są zainteresowani jedynie indywidualną kariera - faktyczne cele policyjnej pracy przestają mieć znaczenie.

O utożsamieniu wspomnianych instytucji z „bogami” mówi także wprost główny twórca serialu, David Simon: „The Wire is a Greek 
tragedy in which the postmodern institutions are the Olympian forces" [Hornby, Simon 2007]. Wypowiedź ta wskazuje na dwa główne wątki, jakimi chcę zająć się w poniższym tekście. Pierwszy dotyczy metafory „bogów” - jej genezy oraz miejsca w opisywanym serialu. Drugi zajmuje się gatunkowym usytuowaniem analizowanego dzieła - jego autor określa go nie tylko mianem „współczesnej greckiej tragedii”, ale także „powieścią wizualną”. Sformułowania te padają zresztą także w tekstach krytyków i dziennikarzy. Obydwa wątki składają się na główny temat mojego tekstu - próbę ukazania The Wire jako popkulturowej aktualizacji refleksji nad stanem współczesnego, sekularnego świata.

\section{Bóg - Ojciec - Prawodawca}

W tradycji judeochrześcijańskiej jej fundamentem jest figura Boga, stworzyciela świata ofiarującego człowiekowi Prawo. Patriarchalna postać nadnaturalnej, boskiej siły, której należy oddawać cześć i będącej gwarantem istniejącego porządku świata stała się matrycą organizowania społeczeństw i ich władzy politycznej. Historia poszczególnych kultur, państw czy imperiów tak zwanego „Zachodu” dostarcza aż nadto przykładów. Klasyczną analizę w tym temacie stanowi dzieło Ernsta Kantorowicza, czyli „Dwa ciała króla”, badające zjawisko średniowiecznej władzy królewskiej. Geneza „boskości” instytucji władzy sięga jednak o wiele dalej. Jednym ze znaczących punktów na drodze jego przemian jest antyczny Rzym. W tym przypadku: państwa, którego kultura była wynikiem silnego oddziaływania wpływów greckich - można mówić o wątku „boskości” zarówno w kwestii jego początków (gdzie władzę sprawowali królowie), czasów republiki jak i - gdzie jest on najbardziej wyrazisty - epoki cezarów. Boskie atrybuty władzy zauważyć można już u zarania dziejów Rzymu: „Król, a później triumfator, nosił szaty Jowisza i występował jako jego ziemska wersja (...)" [Gradel 2002: 34-35]. W czasach republiki o oddawaniu „boskiej czci” można natomiast mówić głównie w kontekście sfery prywatnej - domostwa, w którym taką relację można znaleźć w przypadku pana domu i podległych mu niewolników oraz służących [Gradel: 36-37]. 
Gradel, omawiając powyższe przykłady, czyni kilka, bardzo istotnych zastrzeżeń. Po pierwsze, zwraca uwagę na zupełnie odmienne od zakorzenionego w monoteistycznej tradycji judeochrześcijańskiej rozróżnienie na sferę boską i ziemską. Jak pisze: „pogańska starożytność nie czyniła rozróżnienia między »czcią religijną《 [worship - przyp. aut.] a »polityczną« [honours - przyp. aut.]” [Gradel: 29]. Jednocześnie jednak, w przypadku samych rytuałów religijnych, linia demarkacyjna między bóstwami a ludźmi była zaznaczona bardzo wyraźnie [Gradel: 30]. Jak więc właściwie rozumieć „boskość” przywołanych wyżej instytucji władzy? Nie była ona „boskością” sensu stricto - król, czy pan sprawujący kontrolę nad swoimi niewolnikami, nie byli tożsami bogom. Nie należeli oni do tego samego, co na przykład król rzymskich bogów Jowisz, porządku istnienia. Nadawanie im „boskich” atrybutów (w ubiorze, rytuałach oddawania czci) wynikało natomiast z olbrzymiej dysproporcji władzy i społecznego statusu [Gradel: 34]. Była to więc kwestia polityczna tak, jak w przypadku „boskiej czci” oddawanej cezarom, której początek stanowią decyzje Senatu dotyczące honorowania Juliusza Cezara.

Antyczny Rzym i średniowieczne monarchie dzieli (odpowiednio) poli- i monoteizm. Łączy natomiast - zespolenie instytucji władzy z religią. Jak wykazuje analiza Kantorowicza, to zespolenie w przypadku średniowiecznego monarchy zakładało istnienie „dwóch ciał króla”. Jednego: naturalnego, fizycznego, podatnego na starość, chorobę i inne ziemskie dolegliwości, drugiego zaś boskiego, nadnaturalnego, wiecznego [Kantorowicz 1997: 47]. O ile więc w przypadku władców Rzymu można było mówić tylko o honorowaniu ich „boskimi” atrybutami, o tyle średniowieczny król był już - w swojej dwoistej postaci - ucieleśnieniem Chrystusa. Jego „ciało polityczne” reprezentowało w pełni boską władzę oraz stanowiło religijne wcielenie abstrakcyjnego, wyobrażonego wiecznego bytu danego królestwa. Kantorowicz wspomina o praktyce personifikowania w przedstawieniach ikonograficznych poszczególnych rzymskich prowincji jako sylwetek kobiecych ozdobionych aureolą [Kantorowicz: 79]. Świętość oznaczała tu nic innego, jak ponadczasowe trwanie danej prowincji. Jak wskazuje Kantorowicz, konotacje sformułowań takich, 
jak „Rzym - wieczne miasto”, czy „Wieczna Francja” (lub też „Najjaśniejsza Rzeczpospolita”) dokładnie odzwierciedlają wspomnianą, rzymską praktykę [Kantorowicz: 79].

\section{Bogowie ześwieczczeni}

Przywołanie ze wszystkimi niuansami oraz szczegółami obszernego wywodu Kantorowicza, czy odkryć innych badaczy i badaczek zajmujących się w ostatnich latach tematem suwerenności władzy wykroczyłoby niestety zdecydowanie poza główny przedmiot mojego zainteresowania. Nie rozwijając więc w większym stopniu tego wątku, chcę podsumować jego główny punkt. Jest nim mianowicie religijna sankcja, jaką dysponowała władza królewska, uzasadniając swoje panowanie. Mityczna pozycja Boga jako Stworzyciela i Prawodawcy transponowana była na monarchę. Jak jednak powiązać tą konstrukcję z wypowiedzią bohatera współczesnego amerykańskiego serialu? Jej linearne i dosłowne przeniesienie było by zbyt poważnym uproszczeniem. Chciałbym w tym punkcie przywołać więc koncepcję mobilności kulturowej Greenblatta. Prezentując ją, krytykuje on dwa inne, wielkie modele wyjaśniania dokonujących się w historii kulturowych przemian: „translatio imperii” i „figury” [Greenblatt 2012: 43-45]. Charakteryzują się one jego zdaniem „teleologicznym triumfalizmem jako ich siłą napędową”. W ich miejsce autor proponuje koncepcję „mobilności kulturowej”, odrzucającej myśl jakoby jakakolwiek kultura była kiedykolwiek „stała”, czy „rdzenna”.

Nie zamierzam w rozważaniach nad The Wire bezpośrednio stosować metody analizy zaproponowanej przez Greenblatta. Chcę wykorzystać natomiast powyższe zastrzeżenia wobec linearnych modeli „przenoszenia” treści i wartości kultury. Koncepcja „dwóch ciał króla” nie mogła przetrwać nienaruszona w czasach sekularyzującej się, nowoczesnej Europy. Jej żywotność jest jednak łatwo zauważalna. U zarania współczesnej, demokratycznej europejskiej nowoczesności - to jest Wielkiej Rewolucji Francuskiej - znaleźć można mnogość metafor „ciała” w odniesieniu do zachodzących wtedy procesów politycznych. Obfitość wspomnianego materiału i jego znaczenie analizuje Antoine 
De Baecque w książce The Body Politic: Corporeal Metaphor in Revolutionary France, 1770-1800. Najistotniejsza z punktu widzenia mojej pracy, polityczna reprezentacja „ciała” opisywana przez De Baecque dotyczy momentu przejścia od „ciała króla” do „ciała obywatelskiego”. Jak się okazuje, choć instytucja monarchii zostaje zniesiona, to organiczna metaforyka "ciała" trwa dalej, adaptowana do nowego tworu francuskiej republiki [De Baecque 1997: 8-9]. A następnie, do rodzących się państw narodowych o ustroju demokratycznym, w których suwerenny lud sprawuje władzę (bezpośrednio lub przez swoich reprezentantów).

Nietrudno jest $\mathrm{w}$ powyższym kontekście zrozumieć, dlaczego Simon decyduje się na użycie właśnie metafory „bóstw”. Prezentowane w The Wire organizacje: policja, media, urząd burmistrza, szkoły, związki zawodowe są typowymi instytucjami współczesnej demokracji liberalnej (w tym przypadku w wydaniu amerykańskim). Znacząca większość perypetii, jakie dotykają bohaterów i bohaterki opiera się na temacie ich miejsca i sposobu funkcjonowania w poszczególnych instytucjach. Spektrum relacji i nastawienia poszczególnych postaci rozciąga się z reguly od pełnego konformizmu i skupienia na indywidualnych grach o własną pozycję, przez ciche przystosowanie się, aż do postaw buntowniczych i opozycyjnych. Obserwujemy więc tak różnych bohaterów jak przywołanego już Ervina Burrela oraz - z drugiej strony - detektywa Jimmy'ego McNulty. Ten ostatni bardzo często kontestuje policyjną hierarchię, sposoby pracy czy uległość wobec wpływów polityki. Po drugiej stronie skali mieści się także major „Bunny" Colvin - cichy reformator, decydujący się na radykalny społeczny eksperyment.

Galeria postaci tego 5-sezonowego serialu jest zbyt rozległa, by można ją było w tym miejscu w pełni opisać. Najistotniejszy jest wspomniany schemat, $\mathrm{w}$ ramach którego konstruowana jest fabula The Wire. Pokazanie przez Simona różnych postaw i modeli zachowań służy scharakteryzowaniu poszczególnych instytucji. Na pierwszy rzut oka, wyłaniający się obraz stoi w zgodzie ze zdaniem głównego scenarzysty: „In this drama, the institutions always prove larger” [Hornby, Simon 1997]. Trudno tego nie zauważyć: instytucje „ciskają gromami” (używając metafory Simona) nie tylko w niepokornych reformatorów, 
ale także (czasem przypadkowo) w konformistów i swoich wiernych wyznawców. Reguły gry, pisane przez instytucje, są w zasadzie wszechogarniające i dotyczą także tych, którzy formalnie znajdują się poza przeróżnymi organizacjami ( $\mathrm{w}$ The Wire jest to tylko kilka postaci).

Dzieło z Baltimore było by w tej perspektywie faktycznie przepełnione fatalizmem charakterystycznym dla greckiej tragedii. Nawet słuszne z moralnego czy etycznego punktu widzenia decyzje poszczególnych bohaterów i bohaterek potrafią obrócić się ostatecznie przeciwko nim i sprawie, o którą walczą. Fatalistyczną wymowę serialu podkreśla jego zakończenie. W ostatnim odcinku całej serii widzimy sekwencję ujęć pokazujących dalsze losy postaci i środowisk prezentowanych w dziele Simona (sezon piąty, odcinek „-30-”, 01:26:53). Okazuje się, że mimo indywidualnych starań „wszystko jest tak, jak było”. Zamknięty „za kratkami” gang zostaje zastąpiony przez inny, handel narkotykami trwa w najlepsze; politycy, komisarze i redaktorzy naczelni dalej robią swoje kariery, wciąż korzystając ze słynnej zasady: „ręka rękę myje"; zaś reformatorzy tkwią na swoich - przegranych pozycjach - bijąc głową w mur.

\section{Kawałek Utopii}

Mając jednak na uwadze inne wypowiedzi Simona, powyższa koncepcja wręcz domaga się krytycznej rewizji. Wracam tu więc do zapowiedzianego na wstępie punktu dotyczącego gatunkowego usytuowania The Wire. Sam fakt powoływania się przez Simona na kilka, zupełnie odmiennych tradycji literackich: grecką tragedię z jednej i powieść realistyczną z drugiej budzi wiele pytań. Nazwiska Sofoklesa i Eurypidesa [Tamże] sąsiadują w jego wypowiedziach (oraz krytyków i recenzentów) z Balzakiem, Dickensem czy Tołstojem [Chan, Quack, Simon 2010/2011] [Jameson 2011; The Telegraph 2002]. Do tego, spotkać można teksty analizujące to dzieło na przykład w perspektywie mechaniki gry komputerowej [Mittel 2011]. Sama kwestia niestabilności gatunkowej nowych seriali amerykańskiej telewizji zasługuje zapewne na oddzielne omówienie. $Z$ mojego punktu widzenia najciekawsze zaś wydaje się w tym punkcie czerpanie z tradycji powieści realistycznej. 
Narodziny tego gatunku w XIX wieku powiązać można z rozwijającym się procesem sekularyzacji. Czyni to Susanna Lee, która idąc tropem Lukácsa, Wooda i innych teoretyków literatury analizuje dzieła XIX-wiecznej powieści realistycznej. Jej książka rozpoczyna się wprowadzeniem, na początku którego znajdujemy motto - cytat $\mathrm{z}$,Teorii powieści” Lukácsa: „Powieść jest eposem świata opuszczonego przez Boga” [Lee 2006: 11]. Zdaniem Lee, sekularyzm i rozwój powieści są ze sobą silnie związane: „(...) Odejście Boga staje się formalną bazą i podłożem dla powieści, powieść zaś pokazuje nam czym jest sekularyzm i informuje nas o kryzysach, niepewnościach i potencjale” [Lee 2006: 11]. Z czego wynika taki związek? „Opuszczenie świata przez Boga” jest poczuciem, które wydaje się bardzo dobrze opisywać czas XIX wieku. Gwałtowne przemiany polityczne, zainicjowane wydarzeniami rewolucji francuskiej; rewolucja przemysłowa i urbanizacja; rozwój nauki - wszystkie te procesy musiały przyczyniać się w bardzo dużym stopniu do rosnącego poczucia niepewności. Można w tym miejscu powrócić do kwestii „boskości” władzy monarchicznej. Stracenie króla Francji było by najprawdopodobniej najlepszym (i ekstremalnym) przykładem na „opuszczenie przez Boga”.

Zachwianie obowiązującego ładu i opuszczenie sceny przez dotychczasowych aktorów społecznych i politycznych, a także ustalonych praw czy zwyczajów, wydaje się w oczach obserwujących te procesy tworzyć groźną pustkę domagającą się wypełnienia, by zapobiec niebezpiecznemu chaosowi i upadkowi porządku. Jak wskazuje Lee, w tym momencie do akcji wkroczyć może zarówno polityk, jak i pisarz [Lee 2006: 14-15]. Obaj oferują obietnicę przywrócenia lub obronienia stanu porządku - ocalenia przed chaosem. Powieść, stworzona przez pisarza, wydaje się jednak nieść ze sobą potencjalnie coś więcej - subtelne sproblematyzowanie zachodzących przemian (fabularne, lub strukturalne) daje nam myślowe, intelektualne ramy dla naszej samodzielnej analizy [Lee 2006: 16].

Bezpośrednie deklaracje nawiązywania do klasyków wielkich powieści XIX wieku stoją w zgodzie z końcowym rezultatem zabiegów Simona. The Wire podzielone jest na 5 sezonów (które można traktować jako poszczególne „księgi”), na każdy z nich natomiast składa się 12-13 odcinków („rozdziałów”; poza sezonem 5, liczącym 10 odcinków). 60 godzin 
projekcji serialowego Baltimore wypełnionych jest bardzo szeroką gamą licznych bohaterów pierwszo-, drugo- i trzecioplanowych oraz równie mnogimi, wzajemnie przeplatającymi się wątkami. Znaczenie tych podobieństw i odwołań do powieści realistycznej wybrzmiewa w pełni w powiązaniu z metaforą instytucji jako „bóstw”. Wracam tu do zapowiedzianej wcześniej krytycznej rewizji tezy traktującej The Wire jako nowoczesną, przepełnioną fatalizmem grecką tragedię, ale także jako obraz różnorodnych instytucji, ich mechanizmów i górowania nad jednostką.

Oglądając dzieło Simona, obserwujemy opisywane instytucje z perspektywy ich trwającego upadku. Wspomniane organizacje faktycznie stoją zdecydowanie ponad jednostką - jednak ich wplyw i znaczenie kruszeje. Najbardziej wymownym tego przykładem jest pozycja związku zawodowego dokerów. Przemiany globalnej i amerykańskiej ekonomii powodują, że funkcjonowanie portu towarowego w Baltimore traci rację bytu. Związkowcy (nie zawsze czystymi metodami) walczą o jego ocalenie (to jest o zachowanie swoich miejsc pracy) przed przekształceniem nabrzeża w osiedle apartamentowców. Logika "optymalizacji kosztów”, związana z kruszeniem się przemysłowej bazy i chęcią osiągnięcia jeszcze większej stopy zwrotu, dotyka także serialowej redakcji „The Baltimore Sun” („The Baltimore Sun” w rzeczywistości jest lokalnym wydaniem „The Sun” i największym dziennikiem w stanie Maryland). Obserwujemy zamykanie kolejnych biur na całym świecie, a także cięcia w samej redakcji. Pogoń za sensacyjnymi artykulami, które napędzą sprzedaż i cyrkulację gazety odbija się na jakości dziennikarstwa (wielka afera z seryjnym zabójcą jest w rzeczywistości mistyfikacją dokonaną przez McNulty'ego).

$\mathrm{W}$ tej sytuacji rozpadu instytucje przestają powoli służyć komukolwiek, poza samymi sobie - w tym przede wszystkim kontrolującym je jednostkom. W ich miejscu zaś wyrastają nowe. Idealnym przykładem jest tu starcie departamentu policji z gangami handlującymi narkotykami. „Wojna z narkotykami” oznacza przede wszystkim skupienie się na „siłowych” działaniach operacyjnych. Gdy tylko z ulic znikają posiadający dobry kontakt z lokalną społecznością dzielnicowi, w ich miejsce wkraczają gangi narkotykowe rekrutujące nie mającą zbytnich perspektyw (przede wszystkim czarną) młodzież. 


\section{Zamiast podsumowania}

Jak wskazuje Lee, reakcje na „opuszczenie przez Boga” nie były jednoznaczne. W tak dogłębnej zmianie perspektywy i dotychczasowego ładu można było dostrzegać zarówno groźbę chaosu i odczuwać przed nią trwogę, jak i dostrzegać tworzącą się przestrzeń pełną nowych możliwości [Lee 2006: 12]. „Wizualna powieść” Simona dostarcza - wbrew opisanemu wcześniej fatalizmowi - także drugiej z perspektyw. Pisze o tym Fredric Jameson: „To właśnie w The Wire, zanim rzeczywistość i teraźniejszość zacementują wyłom, udaje się tu i ówdzie na chwilę przebić wizjom utopijnej przyszłości” [Jameson 2011: 372]. Społeczny eksperyment $\mathrm{z}$ depenalizacją narkotyków w wyznaczonym obszarze prowadzony (z sukcesem!) przez majora Colvina zostaje dosłownie rozjechany buldożerami pod wpływem doraźnych interesów politycznych. Nie zmienia to faktu, że wyłom w „oficjalnej”, wydawałoby się bez-alternatywnej rzeczywistości został dokonany. Każe nam to spojrzeć na The Wire nie tylko jako na próbę udzielenia przez jego twórców odpowiedzi na pytania dotyczące kondycji wspótczesnego świata odchodzących w niepamięć „starych bogów” - ale także jako na wezwanie do aktywnego wypełnienia tworzącej się po nich pustki.

\section{Bibliografia}

Chan C., Quack G., Simon D. [2010/2011], Salty, Litigious, Iconoclastic: David Simon on TV as discourse, http://032c.com/2011/salty-litigious-iconoclastic-david-simon-on-tv-as-discourse/ [dostęp 30.09.2013].

De Baecque A. [1997], The Body Politic: Corporeal Metaphor in Revolutionary France, 1770-1800, Stanford University Press, Stanford.

Gradel I. [2002], Emperor Worship and Roman Religion, Clarendon Press, Oxford.

Greenblatt S. [2012], Mobilność kulturowa: wprowadzenie, „Didaskalia” $\mathrm{nr} 106$, Wrocław.

Hornby N., Simon D. [2007], David Simon. Interview, http://www.believermag.com/issues/200708/?read=interview_simon [dostęp 30.09.2013]. 
Jameson F. [2011], Realism and Utopia in The Wire, Wayne State University Press, Detroit.

Kantorowicz E. [1997], The King's Two Bodies. A Study in Mediaeval Political Theology, Princeton University Press, New Jersey.

Lee S. [2006], A World Abandoned by God. Narrative and Secularism, Lewisburg Bucknell University Press.

Mittel J. [2011], All in the Game: The Wire, Serial Storytelling, and Procedural Logic, http://www.electronicbookreview.com/thread/firstperson/serial [dostęp 30.09.2013].

"The Telegraph" [2009], The Wire: Arguably the Greatest Television Programme Ever Made, http://www.telegraph.co.uk/news/uknews/5095500/ The-Wire-arguably-the-greatest-television-programme-ever-made.html [dostęp 30.09.2013]. 